\title{
ONTWIKKELING EN PERSPEKTIEF IN SUID-AFRIKA SE INTERNASIONALE BETREKKINGE
}

Vooraf 'n woord van hartlike dank vir die eer om genooi te word om deel te neem aan hierdie reeks van interfakultêre lesings.

My bande inet hierdie belangrike sentrum van geleerdheid was tot dusver, helaas, so dun dat hulle byna onsigbaar was en daarvoor moet ék die vernaamste skuld dra en nie u nie. 'n Oom van my was jare gelede hoof van die Hoër Volkskool, en dit was nog in sy tyd dat ek die vorige keer Potchefstroom besoek het. Ek ken enkele van $u$ hoogleraars, maar nie goed genoeg nie.

Origens, vrees ek, was my opvattinge van Potchefstroom en sy werk maar alte dikwels gekleur deur die soort skertsende stories wat buitestaanders graag oor $\mathrm{u}$ herhaal, soos die stokoue wat ek as kind nog van niemand minder nie as my vader gehoor het: die een van Petrus wat 'n nuwe aankomeling in die hemel ontvang en rondbegelei het. Hulle het by ' $n$ alleenstaande gebou met toe deure en geslote luike gekom, en op die vraag wat dít dan beduie, het Petrus geantwoord: „Sjuut, dit is die verblyfplek van die Doppers, maar moet hulle nie steur nie: hulle dink hulle is alléén hier".

$\mathrm{U}$ uitnodiging aan my en my verskyning hier vanaand is die allerkragtigste weerlegging van daardie beskouing: dit is ú deure en luike wat oop staan, en as daar selfisolasie was, dan het dit van mý kant gekom en nie van u nie.

Ek is ook gedagtig daaraan dat uit Potchefstroom nie lank gelede nie aan Suid-Afrika een van die mees indringende en reddende nuwe Afrikaanse woorde van ons tyd gegee is, toe 'n hoogleraar van hierdie Universiteit die begrip van verkramping of verkramptheid oor die land losgelaat het met verreikende en vrugbare gevolge.

En om tot die tema van hierdie reeks van lesings te kom: ontwikkeling en perspektief impliseer duidelik geen statiese, verdedigende, en in sigself gekeerde beskouing van ons toestand en vraagstukke nie; wel 'n dinamiese, voorwaartse en ondernemende instelling van die gees.

Só 'n instelling het in die laaste tyd opvallend na vore getree op die gebied waaroor u my gevra het om vanaand met $u$ te praat: dié van Suid-Afrika se internasionale betrekkinge. Hier is daar inderdaad ontwikkeling en verandering 
in die lug en 'n gees van verwagting en avontuur soos ons land in die meer as twintig jaar sedert die Tweede Wêreldoorlog nie geken het nie. Ons is besig om gesigte te sien van ons rol in Afrika en die wêreld wat vyf of tien jaar gelede nog byna ondenkbaar was, en dit kan selfs wees dat ons staan by die geboorte of die wedergeboorte van 'n besef van nasionale roeping en bestemming, grootser as enigiets wat ons volk sedert die Groot Trek en die Tweede Vryheidsoorlog belewe het.

$\mathrm{U}$ het my gevra om hieroor met u gedagtes te wissel, en ek doen dit sonder pretensies van geleerdheid in hierdie sake en selfs nie eens as voltydse waarnemer van ons buitelandse beleid en betrekkinge nie. ' $n$ Koerantman, veral ' $n$ meningvormende koerantman, kan nouliks spesialiseer in die mate wat 'n akademikus as gewens beskou. Hy is uiteraard 'n impressionis; maar dit is moontlik dat hy juis daarom sommige van die breë lyne raaksien terwyl deegliker en meer gedissiplineerde geeste nog swoeg om die besonderhede baas te raak.

Aldus breed gesien, het in die afgelope twintig jaar ' $n$ dramatiese en byna verbysterende verandering in Suid-Afrika se posisie in die wêreld plaasgevind. Die internasionale raamwerk waarbinne ons as land meer as anderhalwe eeu lank bestaan het, het binne 'n enkele dekade vir die grootste deel ineengestort, sodat ons blootgestel geraak het aan strominge en magte waarvan ons die regstreekse inwerking tevore nie geken het nie.

Dit is vanselfsprekend dat ons vroeë reaksie op hierdie omwenteling in ons omstandighede verward en wesenlik verdedigend sou wees. Dit is ewe vanselfsprekend dat ' $n$ volk wat sy sout werd is, ná die eerste skokke geleidelik tot verhaal sou kom en die nuwe omgewing wat rondom hom tot stand gebring is, sou begin aanvaar en sy plek en rol daarin sou begin soek en omskrywe. Ons staan vandag midde-in daardie oorgang en daardie aanpassing, en dit is sommige van die vraagstukke van hierdie proses wat ek vanaand met u wil bespreek.

Die raamwerk waarbinne ons so lank ons nasionale bestaan gevind het, was 'n Britse raamwerk. Dit was só langdurig dat ons soms beswyk het voor die illusie dat dit permanent kon wees. $\mathrm{O}$ ja, ons het geveg vir ons nasionale selfbeskikkingsreg, ons vryheid om ons eie lot te bepaal, 
maar tot geruime tyd ná die Tweede Wêreldoorlog nog was ons bewuste of onbewuste veronderstelling dat "There will always be an England", in die sin dat ons in Afrika onbepaald omring sou bly deur Britse of Brits-bevriende gebiede en dat die seetoegange tot Suid-Afrika deur 'n vriendskaplike Britse seemag effektief beheer sou word so ver as wat ons vooruit kon dink. Ons buitelandse betrekkinge sou bly wat dit sedert die begin van die negentiende eeu hoofsaaklik en meestal byna uitsluitend was, naamlik ons betrekkinge met Brittanje. Ons verhoudinge, verhoudinge van antagonisme sowel as van samewerking, was in die eerste plaas op Londen gerig. Brittanje was in die buiteland ons vernaamste afkeer en ons vernaamste liefde, en dít was die sentrale feit van ons internasionale bestaan waaróm ons ander internasionale verhoudinge hulself gegroepeer het.

Só sterk was die illusie van permanensie dat die vrywording van die grootste deel van Asië van koloniale oorheersing kort ná die oorlog ons grootliks onbewoë gelaat het. Dit was vir die meeste Suid-Afrikaners tot diep in die vyftigerjare ondenkbaar dat dieselfde proses in dieselfde tempo in Afrika voor die deur gestaan het. Ons het as land byvoorbeeld die verreikende betekenis van die Suez-krisis van 1956 nie verstaan nie: dat dit die doodsklok was van die ou Wes-Europese imperialisme in Afrika, gesamentlik gelui deur die Verenigde State en die Sowjet-Unie, wat in hul magstryd mekaar moes oorbie in hul anti-kolonialistiese ywer.

Met Suez het Brittanje en Frankryk immers kennis gekry dat die gebruik van geweld vir ouderwetse imperialistiese oogmerke, of oogmerke wat so vertolk kon word, in die nuwe omstandighede onhoudbaar geword het. 'n Imperialistiese skietery op 'n nie-blanke volk het onbetaalbaar duur geword met die oog op daardie moondhede se verswakte wêreldposisie; en natuurlik, wanneer die finale sanksie van militêre mag eers uit 'n koloniale situasie verwyder word, wanneer jy in laaste instansie nie meer kán of wil skiet nie, moet jy maar so vinnig en met soveel grasie as moontlik toegee en dan padgee.

Dit is wat Brittanje, Frankryk en België in die jare ná Suez sou doen, en vanuit Suid-Afrika gesien, verskriklik halsoorkop sou doen; en omdat ons die onderliggende kragte nie goed verstaan het nie, het ons hulle dit bitter kwalik geneem. Ons het ons verlustig in beskuldiginge van papheid 
en dekadensie, asof dít die proses kon teenhou, in stede van ons in te stel op die onvermydelike, naamlik die nagenoeg totale likwidasie van die kolonialisme in Afrika binne weinig meer as tien jaar.

Op die politieke vlak was daar in Suid-Afrika in die vroeë en die middel-vyftigerjare betreklik min konstruktiewe denke oor die Afrika-revolusie. Ons het hoofsaaklik kennis daarvan geneem om dit af te wys. Ons het gewens iemand wou dit stopsit. Ons het die euwels van die ontwikkeling beklemtoon ten koste van die geleenthede, en deur ons algemene houding het ons 'n beeld help skep van Suid-Afrika as 'n vriend van die ondergaande koloniale orde, en trouens as ' $n$ deel en 'n sluitstuk daarvan. Ons het toegelaat dat ons in 'n valse posisie gedruk word, en ons het meegewerk daartoe.

Dit lyk vandag vreemd dat ons landsbeleid in die middelvyftigerjare, toe die anti-kolonialistiese omwenteling in Afrika juis besig was om momentum te kry, gestel is in terme van baasskap, van permanente blanke heerskappy oor nie-blanke volke, met ander woorde van naakte, onverbloemde kolonialisme en imperialisme. Dit was natuurlik dat ons blank-geleide orde hier 'n mikpunt van die swart uhuru-beweging sou word, maar ons het saamgespeel deur feitlik in die kol te gaan staan.

Dat dit onder 'n regering van Afrikanernasionaliste gebeur het, is des te merkwaardiger as ons daaraan dink dat die Afrikanervolk tog die voorste anti-kolonialistiese volk van Afrika was in hierdie eeu en ook in die vorige. Dit was ons voorvaders wat die vlag van vryheid van vreemde oorheersing in hierdie kontinent gehys het en vir 'n onafhanklike eie nasieskap geveg het. Die eerste dodelike wonde vir die ou Westerse imperialisme in Afrika is toegedien deur die Boererepublieke. Dit is hulle wat hierdie anti-kolonialistiese eeu geopen het met ' $n$ anti-kolonialistiese stryd wat die verbeelding van die wêreld aangegryp het en selfs menige swart nasionalis in Afrika geïnspireer het. Des te ongelukkiger was dit dat, toe die tyd van die ondergang van die Wes-Europese imperiums in Afrika aanbreek, ons land die indruk gewek het dat ons nie maar net die metode van bevryding afkeur nie, nie maar net die oorhaastigheid en gebrek aan voorbereiding nie, maar die beginsel van nasionale vryheid self wanneer dit kom by volke van 'n ander kleur as onsself. Ons het in die hande van ons ergste vyande gespeel deur toe te laat dat ons so nou vereenselwig word met 'n verdwynende orde waarin 
sy hoof-eksponente self hul geloof verloor het.

Daar was ander tekortkominge in ons buitelandse beleid in die na-oorlogse tyd, maar m.i. niks wat naastenby vergelyk kan word met hierdie valse posisie waarin ons ons begewe het nie.

Tot sekere hoogte het ons die nagevolge van daardie afwyking nog nie heeltemal afgeskud nie. Maar daar was in die vyftigerjare tog ook 'n ander kant, ' $n$ reddende ander kant. Gelyktydig met die verbeeldinglose en negatiewe benadering van die Afrika-revolusie wat ek gekritiseer het, was daar 'n ontwikkeling in die Afrikaans-Nasionale denke aan die gang, baie nader en trouer aan die suiwer lyn van ons geskiedenis.

Ek bedoel die worsteling in Afrikaanse intellektuele en geestelike kringe met die grondprobleem van vryheid binne ons eie grense. Die prikkel daartoe het nie vernaamlik van buite gekom nie. Dit het trouens gang gekry lank voordat die Afrikarevolusie op dreef gekom het. Die belangrike kerklike kongres oor die Bantoevraagstuk waar gebiedskeiding as toekomsrigting aangedui is, het so vroeg as 1950 plaasgevind. Nie vrees vir wat in Afrika aan die kom was het die aanleiding daartoe verskaf nie, maar eerlike wroeging oor die vraagstukke van rasseverhoudinge in Suid-Afrika.

Die denkers van 'n volk wie se vernaamste trots sy suksesvolle stryd teen 'n vreemde imperialisme was, het hulself afgevra of hulle nie self besig was om te verval in die euwel wat hulle so lank beveg het nie: eers imperialistiese oorheersing van die Bantoevolke deur die blankes, en naderhand noodwendig, omdat so 'n heerskappy deur hulle eie geskiedenis bewys is as op die duur gedoem, 'n swart imperialistiese oorheersing van die blanke nasie.

Gestel voor die keuse van permanente dominasie en min of meer geleidelike abdikasie, het ons intellektueles en geestelikes in die vroeë vyftiger jare hul pad gevoel na die prinsipiële antwoord wat heelwat later ons amptelike standpunt sou word. Dit is dat die Afrikaners, en meer algemeen die blankes van Suid-Afrika, geen setlaarsminderheid is soos koloniale minderhede elders nie, maar ' $n$ volk van Afrika in sy eie reg. Sy geskiedenis, sy Westerse vryheidsbeskouinge en sy sin vir geregtigheid maak 'n beleid van permanente dominasie vir hom verwerplik. Dit is immoreel en daarom op die duur onprakties. Maar abdikasie in die sin van die uitlewering van sy vryheid aan 'n andersoortige meerderheid, is selfs nog 
onhoudbaarder. Ons het nie verslawing van bo af beëindig om vervang te word deur verslawing van onder af nie. As dominasie verkeerd en selfvernietigend is, dan is dit so vir Bantoe, Brit én Boer, en dan moet die neiging daartoe oral en altyd by almal beveg word. Dus: geen eie dominasie van ander nie, maar ook geen abdikasie wat die weg oopmaak vir dominasie déúr ander nie.

So is in die jare van die vorige dekade die idee van afsonderlike ontwikkeling tot aparte vryhede op 'n grondslag van territoriale skeiding gebore, of miskien juister gestel: weer gebore, want wesenlik nuut was dit nie. Dit was inherent in die Afrikanernasionalisme, en dat dit so ' $n$ moeilike en worstelende opkoms gehad het, was maar net 'n bewys van die korrupsie van ons denke wat binne die Brits-imperiale raamwerk plaasgevind het. Ons het toegelaat dat ons vergesigte, ons gehegtheid aan die prinsipiële, ons besef dat jy geen regte aksie kan hê sonder voorafgaande regte denke nie dat dit verwater en vertroebel word deur wat soms genoem word praktiese en realistiese oorweginge.

In werklikheid was dit die sogenaamde onpraktiese en onrealistiese geleerdes en geestelikes wat vir ons land die regte pad aangedui het, nie alleen in sy binnelandse groepsverhoudinge nie, maar ook en veral in sy buitelandse verhoudinge. Want op 'n grondslag van dominasie, baasskap, permanente heerskappy, is vrede binne Suid-Afrika nog denkbaar vir 'n korter of langer tyd, maar vrede na buite toe in ons eeu en omstandighede 'n heeltemal ydele droom. Die weg van binnelandse sowel as buitelandse vrede vir Suid-Afrika is klaarblyklik die dekolonisasie of ontvoogding van ons nieblanke volke, en vir sover dit nie in één staatstruktuur moontlik is nie, moet dit in aparte strukture en aparte gebiede gedoen word.

Hierdie beskouing is in die vyftigerjare konsekwent uitgewerk in Afrikaanse akademiese en kerklike kringe terwyl ons posisie in Afrika nog ver van dringend was, en die proses is trouens weinig beïnvloed deur wat aan die kom was, want daar was toe nog geen sterk gevoel van krisis oor die Westerse dekolonisasie in Afrika nie. Ons het nie eintlik geglo dat hierdie dinge ons spoedig sou raak nie.

Daardie illusie van veiligheid en normaliteit is eers behoorlik verpletter in die klimakteriese jaar 1960. Dit was die jaar van mnr. Harold Macmillan se besoek, van die P.A.C. 
onluste, van die ineenstorting ná vrywording in die Kongo, en les bes, van ons republiek-referendum.

Hoe verknog ons gebly het aan die ou en vertroude Britsimperiale raamwerk rondom ons in Afrika, het ons reaksies op mnr. Macmillan se Kaapse toespraak geopenbaar. Hy het vir ons die klaarblyklike boodskap van die tyd gebring: dat die dekolonisasie in Afrika, die wind van verandering, onkeerbaar is en dat ons al hoe meer op onsself aangewys sou wees vir ons toekomstige internasionale heil. Brittanje sou hom in sekere opsigte van ons moet distansieer. En van alle kante het dit toe opgeklink: Hy gooi ons vir die wolwe! Met ander woorde, 'n erkenning dat ons nog altyd in die Britse slee was, dat dit lekker en veilig gevoel het daar, en dat ons graag verder sou wou saamry. Komende van die tradisioneel imperiaaldenkende seksies van die bevolking, was dit 'n natuurlike reaksie. Die ironie was dat dit ook van anti-imperiale Afrikaanse kant gekom het, van die kant wat altyd aangedring het op die afsny van bande. Mnr. Macmillan se verklaring van Suid-Afrika se onafhanklikheid was ook vir sommige van óns 'n emmer koue water.

Dit is opgevolg deur die Sharpeville-onluste, wat niks anders was as die inslag van die Afrika-revolusie in ons stedelike gebiede nie, en daarná deur die verskriklike en blykbaar onherstelbare debakel in die Kongo.

Ons nasionale ontwaking tot ons nuwe wêreldposisie en die werklikhede van Afrika dateer van daardie tyd af, en dit was 'n bitter koue en troostelose wakker word. Maar dit het ook gedien om ons terug te werp op die prinsipiële fondamente wat vroeër gelê was en in rustiger tye tot groot hoogte veronagsaam gebly het. Reeds in die jaar 1959 het die beleid van vrywordende Bantoetuistes deurgebreek tot die praktiese politiek, toe dr. Verwoerd dit as amptelike koers vir Suid-Afrika uiteengesit het. Met ander woorde, die beginsel van dekolonisasie of ontvoogding het ook óns beginsel geword, hoewel ons dit uiteraard nie met die roekelose haas van die Wes-Europese moondhede kon toepas nie. Ons moet saam lewe met wat ons doen, terwyl hulle kon padgee. Chaos in Nigerië tas nie die lewe van Brittanje aan nie, en België kan voortbestaan terwyl terroriste die Kongo uiteenskeur. Ons kan ons nie ewe gerieflik afsluit van wat in die Transkei of Lesotho aan die gang is nie.

Maar met daardie 1959-verklaring van dr. Verwoerd is 
Suid-Afrika weggevoer van die onmoontlike koers van baasskap en terug na die konsepsie van voogdyskap met sy implikasie van uiteindelike ontvoogding. Ons was besig om ons prinsipieel reg te ruk en weerbaar te maak vir ons bestaan in 'n nuwe Afrika en 'n nuwe wêreld.

Uit daardie tyd dateer ook die prysgewing van ons tradisionele aandrang op die inlywing van die Protektorate. Vrywordende Protektorate was immers nie onverenigbaar met vrywordende Bantoetuistes nie. Hulle kon ingepas word by die nuwe Suider-Afrikaanse patroon wat dr. Verwoerd geleidelik besig was om te ontvou. Ek sê besig was om te ontvou, want die eerste aanvaarding van die beginsel van selfbeskikkingsreg vir die Bantoevolke in hul eie gebiede is eers in 1962 opgevolg deur die definitiewe plan vir die Transkei, en daar is tot vandag toe nog geen tweede Transkei nie.

Maar ons sou voortaan, in ons verdediging van ons orde voor ons eie gewete en die wêreld, ten minste staan op beginsels wat in die teorie onaantasbaar is, hoe ook al oor die uitvoering in die praktyk getwyfel mag word. Ons erkenning van die selfbeskikkingsreg van die nie-blanke volke onder ons voogdyskap, het ons landsbeleid op 'n fondament geplaas wat dit in die vyftigerjare nie gehad het nie, tot groot skade vir ons wêreldposisie. As $u$ in daardie jare Suid-Afrika moes verduidelik en verdedig teen kritiese beskouinge, soos ek dikwels moes doen, sal $\mathrm{u}$ weet hoe swak ons dialektiese skanse toe nog was, hoe maklik om te deurbreek, nie met die wapens van vreemde ideologieë nie, maar met argumente gehaal uit ons eie geskiedenis en ons eie beste opvattinge. Ons wat Britse baasskap oor die Afrikaners en Suid-Afrika beveg het, het werklik nie die hart gehad om die idee van Afrikanerbaasskap oor ander volke van Afrika goed te praat nie, en vir my bly dit dr. Verwoerd se grootste deug as staatsman dat hy ons verlos het van die verpligting om die onverdedigbare te verdedig. Suid-Afrika is aan homself nie te verkoop nie, laat staan aan die wêreld, anders as 'n land wat nasionale vryheid vir sy verskillende volke in die vooruitsig stel, hoe onmeetlik moeilik daardie ideaal in ons omstandighede ook al te bereik is.

Dit is dan wat die skokke van 1960 by ons ingedryf het: aan die een kant die onweerstaanbaarheid, ook in Afrika, van die nasionale vryheidsidee, en aan die ander kant die noodsaaklikheid daarvan om die ontwikkeling tot vryheid 
binne evolusionêre bane te hou, sodat dit nie hand-uit ruk soos in die Kongo of ontaard in rewolusionêre swart imperialisme soos dié wat in die P.A.C.-onluste in ons stede opgedoem het nie. Vryheid vir ons Bantoevolke, ja, maar met behoud van die verwronge vryheid van die blanke nasie, ook in die belang van daardie Bantoevolke en hul ontwikkeling. Want ons kan en sal die noodsaaklike hulp aan hulle nie verskaf as onsself nie 'n sekere minimum van veiligheid het en voel nie. Geen nasie sal ander help bevry of ontwikkel ten koste van homself en sy lewe nie.

Ook in ' $n$ ander belangrike opsig het 1960 beslag gegee aan ons nuwe wêreldposisie. $\mathrm{Ek}_{k}$ verwys na die republiekreferendum van daardie jaar. Net soos met die denke oor die Bantoevraagstuk in die jare vyftig, was die kwessie van republiekwording bewustelik maar weinig gekoppel aan ons buitelandse betrekkinge, hoewel dit klaarblyklik was dat ons voortgesette lidmaatskap van die Statebond ter sprake moes kom.

Ons vernaamste argument was dat republiekwording 'n noodwendigheid en 'n noodsaaklikheid was in die proses van nasiebou, waarmee vernaamlik bedoel is die eenheid van Afrikaans- en Engelssprekendes. Maar dit het belangrike implikasies na buite gehad. Dit het dringend geword om, met die oog op wat op internasionale gebied gedreig het, hierdie ou binnelandse strydpunt uit die pad te kry, en dit kon net op één manier van die nasionale agenda geskrap word, nl. deur die laaste Britse simbool uit ons konstitusie te verwyder. Buite ons was die Britse raamwerk aan die instort. Geen tyd was mér geleë om ook die oorblyfsels van die Britse raamwerk bínne Suid-Afrika te verwyder nie. Mnr. Macmillan se kennisgewing dat ons voortaan in die internasionale raadsale meer op ons eie voete moes staan, en die republiekreferendum was twee aanvullende aspekte van ons groei tot staatkundige volwassenheid. Ons moes ontslae raak van ons Britse fopspene, en in dié sin het dit, van agterna gesien, 'n goeie ding geblyk te wees dat ons met republiekwording ook ons Statebondslidmaatskap kwyt was. Dit het ons alleenheid verhoog, juis in 'n tyd toe die wêreldmening as gevolg van Sharpeville tot ' $n$ fantastiese hoogtepunt teen ons opgesweep geraak het, maar dit was 'n alleenheid wat ons goed te staan gekom het. Illusies van veiligheid het verdwyn, illusies dat êrens op die agtergrond tog nog Britse beskerming 
te vinde was; ook illusies by ander dat ons eintlik nog maar 'n soort Britse kolonie was wat deur Britse druk tot geleidelike integrasie en 'n bedeling van een mens, een stem in ' $n$ eenheidsgemeenskap beweeg kon word. In die begin van hierdie dekade het 'n onafhanklike Suid-Afrika dus voor die oë van die wêreld vir die eerste keer geïsoleerd en alléén gestaan vir almal om te sien: propagandisties gesproke 'n muishond, maar onteenseglik 'n selfstandige en eiesoortige persoonlikheid, en geweldig taai daarby.

Ek het ' $n$ rukkie stilgestaan by ons gebreke en versuim vóór 1960 omdat ek glo ons kan uit ons foute méér leer as uit ons suksesse. Maar daar is ook veel te leer uit die manier waarop Suid-Afrika hom in die sestigerjare reggeruk het en die verskerpte dreigemente en bedreiginge van die nuwe dekade op talle vlakke van ons nasionale lewe gehanteer het.

Die P.A.C.-onluste en die kwaai internasionale reaksie daarop het ons 'n duidelike insig gegee in die dubbele aard van die gevaar waarvoor ons as gevolg van die Afrika-revolusie te staan gekom het. Dit was nie maar net 'n aanslag van binne nie, nie maar net 'n kwessie van ondermyning, oploop en opstand binne ons grense nie, waarmee ons met die nodige inspanning wel kon afreken. Hierdie binnelandse aanslag het aansluiting gemaak met die ouer propaganda-aanslag van buite, wat ook binne 'n paar jaar méér as maar net 'n propagandaaanslag sou word. Binnelandse omwentelinge en buitelandse druk was die twee punte van die knyptang waartussen ons vasgedruk en pap gedruk moes word. Van buite af was dit, soos ek gesê het, hoofsaaklik 'n aanslag van propaganda tot 1960. Daarná het dit venyniger geword en oorgegaan in 'n strewe na sanksies, na boikot en blokkade, en in laaste instansie na militêre inmenging.

Die dubbele bedreiging het sommige van die beste hoedanighede van ons land en sy bevolking te voorskyn geroep, ook sommige van die beste hoedanighede in die AfrikaansNasionale politieke leiding. In die eerste plaas het die bestryding van ondermyning en revolusionêre agitasie die allerhoogste voorkeur gekry, nie alleen negatief op die polisievlak nie, maar positief deur die verwydering van griewe en wrywinge, deur yweriger aandag aan die lone en werksomstandighede van die swart arbeiders en aan hul behuising. Daar het meer gang gekom in die ontwikkelingsplanne vir die nie- 
blanke volke en in die skakeling van die verskillende owerhede met hulle.

Terselfdertyd is die versterking van Suid-Afrika na buite, versterking in die letterlike sin van bewapening en die grootste moontlike selfgenoegsaamheid, met krag aangepak. SuidAfrika moes ' $n$ vesting word, na buite so moeilik aantasbaar en so onneembaar as moontlik, en na binne stewig en verenig met ' $n$ meedoënlose hand op gevaarlike elemente wat die rol van 'n Trojaanse perd vir die vyande buite ons poorte kon speel.

Dit is moontlik dat ons in die jare ná Sharpeville soms albei soorte gevare oorskat het, dat daar 'n mate van oorversekering was, byvoorbeeld in die strengheid van ons binnelandse veiligheidsmaatreëls sowel as in ons militêre besteding. Maar in so 'n toestand waarin die veiligheid en stabiliteit van 'n hele beskawing op die spel staan, is 'n oorskatting van gevare klaarblyklik te verkies bo 'n onderskatting daarvan, en dit is in elk geval te vroeg om hierdie vraag juis te beoordeel: die bedreiginge is nog ver van verwyder, hoewel die ergstes in die afgelope jaar 'n sekere onmiddellikheid verloor het.

Dit is ' $n$ ironiese feit dat die drif agter die sanksie-beweging teen Suid-Afrika afgeneem het in die mate waarin dit uit die sfeer van propaganda afgebring is na die vlak van 'n praktiese oorweging van weë en middele. Niks het die geesdrif vir aktiewe optrede teen Suid-Afrika só getemper as die oorweging van wat dit sou kos nie - nie maar net wat dit sou kos aan ontwrigting van die internasionale handel, aan oorlogsvlote en soldate om 'n blokkade en militêre inmenging deur te voer nie, maar ook aan langdurige onrus en eindelose probleme oor die ganse Suider-Afrika. Dit het in menige opsigte ten gunste van ons getel dat hierdie sestigerjare ook die uitbreiding en verhewiging van die stryd in Viëtnam gebring het, maar veral miskien in hierdie opsig: Viëtnam het vir die leidende moondheid van die Weste en baie ander 'n les geleer in die gevaar van internasionale verpligtinge wat nie van die begin af end-uit deurgedink was nie. Die skepping van ontbering, van spanninge en op die ou end van chaos in Suider. Afrika open 'n perspektief waarvoor enige realistiese plannemaker, hoe vurig sy afkeer ook al vir ons, noodwendig moet terugdeins. In die sentrums van werklike mag in die Weste, en 'n mens vermoed soms selfs in Moskou, is die planne vir 
sanksies, vir 'n blokkade en vir militêre inmenging teen Suid-Afrika net bespreek om verwerp te word as waansinnig in die teenswoordige omstandighede.

En al die tyd was die gedugtheid van ons voorbereiding vir daardie moontlikhede 'n argument van toenemende krag. Daar kan geredeneer word of en in welke mate ons internasionale gewildheid in die afgelope sewe jaar gegroei het, maar dat die respek gestyg het vir Suid-Afrika se militêre en ekonomiese mag en vir sy vermoë om ontsettende rekenskap van homself te gee, kan nie betwyfel word nie.

'n Nyweraar uit die buiteland wat daar in ons geweste met buitelandse sowel as Suid-Afrikaanse vakmense te doen het, het die verskil tussen die buitelanders en die Suid-Afrikaners onder sy beheer soos volg opgesom:

Die buitelandse operateur sal vir jou twee weke vóór die tyd sê dat sy masjien uitgeslyt is en een van die dae gaan breek, en dus nagesien moet word. As dit nie gedoen word nie, sal die masjien ook werklik breek, en die operateur sal terugstaan en wag dat ' $n$ bevoegde werktuigkundige dit moet kom herstel. Die Suid-Afrikaner sal niks vooruit sê nie. Miskien sien hy werklik nie 'n breekspul kom nie. Maar wanneer sy masjien nie meer wíl nie, sal hy self inspring en dit ná 'n uur of wat weer aan die gang hê.

Dit is stellig 'n alte eenvoudige beeld van wat met SuidAfrika ná 1960 gebeur het. Maar dit is tog waar dat enorme reserwes van improvisasie, van Boerevernuf as $u$ wil, deur die krisis van die sestigerjare onder die Suid-Afrikaner opgeroep is. Die volle verhaal moet nog vertel word, want dit is ook vir die toekoms besielend: hoe ons nyweraars en tegnici in die aangesig van boikotte begin maak het wat ons aan militêre toerusting tot dan toe ingevoer het; hoe ons handelaars uitgegaan het en markte gevind het vir produkte wat uit sekere lande uitgesluit is; hoe selfs ou markte langs omweë behou is; hoe in die algemeen mense en instansies wat vroeër op 'n intensiteit van sestig of sewentig persent gewerk het, onder die druk van die tyd hul inspanning van gees en spier tot honderd persent opgeskuiwe het. $U$ onthou die opwindende dag toe ons Lugdiens, met die sluiting deur die Afrika-lande van hulle lug vir ons verkeer, aangekondig het dat hy sy Europese diens in stand hou deur heel rondom Afrika na Las Palmas te vlieg in stede van dwarsoor die kontinent. Ons tyd wemel van ander en miskien, as hulle bekend was, 
skouspelagtiger antwoorde op sulke vyandige uitdaginge.

Ons het ons daarop toegelê om 'n vesting te word, en ons hét dit geword in die oë van die wêreld. Vandag word ook in die kringe van ons mees aktiewe vyande met onmeetlik meer respek van Suid-Afrika gepraat as vyf, ses jaar gelede. Die drome van 'n maklike oorwinning deur binnelandse opstand en buitelandse inmenging wat in die vroeë sestigerjare teen Suid-Afrika gedroom is, het volkome verdamp. Die effektiewe wil om ons by te kom en aan te tas, was in sewe jaar nie swakker as nou nie. En dit geld nie net in die Westerse hoofstede nie. Dit is waar ook van die wildste Afrika-state, wat in elk geval nie anders as deur guerilla-aksie teen ons kan optree nie, en wie se hoofstrategie dit daarom is om die Westerse moondhede teen Suid-Afrika in beweging te bring. Hulle gevoel van magteloosheid het toegeneem namate ons krag gegroei het en namate hulle internasionale aansien weens onderlinge verdeeldheid en binnelandse moeilikhede afgeneem het. Die Afrika-revolusie het sy glans verloor en daarmee ook veel van sy suidwaartse dryfkrag.

Wat ons wêreldposisie betref, het ons 'n tydperk van sukses agter die rug wat ons vanweë die nog altyd hewige propaganda-inspanning téén ons dikwels nie goed genoeg besef nie. Ons beleid van verskansing en vestingbou het eintlik bowe verwagting geslaag.

Maar dit is nie die einde nie, maar 'n begin. Laers word getrek en versterk, nie om permanent in te bly nie, maar om kragpunte te vorm vir voorwaartse bewegings na buite toe wanneer die tyd daarvoor ryp is. Dit kan wees dat die oorwegend verdedigende fase in ons houding teenoor die buitewêreld nou oorgaan in iets anders wat in baie opsigte nog veel meer van ons gaan verg, veral omdat nuwe hoedanighede daarby te pas kom.

In een stadium van ons lotgevalle, nie so lank gelede nie, het dit baie sterk gelyk asof ons ons sou moes versoen met die posisie van 'n Israel in Afrika. Ek bedoel dat ons ons sou moes klaarmaak om aan die suidpunt van die kontinent vasgedruk te word in 'n solied vyandige omgewing soos die Joodse staat in die Arabiese wêreld, wat in 'n toestand van skynbaar permanente beleg verkeer van die kant van sy onmiddellike bure. Dit was geen aangename vooruitsig nie, en ons leiers het selfs in ons donkerste ure hul woorde nie só ingespan dat hulle ' $n$ uiteinde van isolasie in Afrika 
bevorder het nie. Hulle het voortgegaan om te praat oor ons toekomstige rol in Afrika as die vasteland se mees gevorderde staat, en oor die moontlikhede van samewerking en van bystand aan die agterlike Afrika-state. Terwyl ons aan die vesting gebou het, het ons die hand van samewerking uitgestrek gehou, al het dit oor 'n lang tyd na 'n nuttelose gebaar gelyk voor die uitinge van vyandigheid en haat wat van hoër op in Afrika gekom het.

Met die vrywording van die Protektorate en die verswakking van die saamhorigheid van die Afrika-state het die uitsig aansienlik verander. Die geleenthede is besig om voor ons oop te gaan. Die druk teen ons is nie langer solied nie. Ons het reeds begin met uitvalle uit die vesting na buite toe, en ons Eerste Minister gee die hoogste voorrang aan wat hy noem die taak om Suid-Afrika in die wêreld in te lei na sy regmatige plek onder die nasies.

$\mathrm{Om}$ in besonderhede met $\mathrm{u}$ te bespreek hoe ons vir ons so 'n voorwaartse beweging toegerus is, sou my te ver voer. Ons is in elk geval reeds ' $n$ aansienlike afstand verwyderd van die onverskilligheid, die negativistiese en die amateuragtigheid van die vyftigerjare. In sake soos die hantering van die Suidwes-geding en die Rhodesiese vraagstuk het Suid-Afrika, naas taaiheid en fermheid, ook 'n kundigheid en 'n behendigheid geopenbaar wat eerbied afgedwing het. Ons voorraad diplomatieke ervaring is nie gering nie, en in die sakewêreld, in die kerke, aan die universiteite en in die politiek is daar 'n opkomende bewustheid van roeping en bestemming buite ons grense. Ons wil handel en ons wil help, ons wil vriende win en betrekkinge op 'n groot verskeidenheid van vlakke ontgin. Of ons die vermoëns het, aan geld en bowenal aan toegeruste manne en vroue, om die beste te maak van die geleenthede wat reeds ontstaan het en nog gaan ontstaan, kan ons gerus maar betwyfel. Dit sal ons nie kwaad doen om in hierdie geval ons kragte te onderskat en ons dienooreenkomstig met bekwame spoed beter toe te rus nie.

Maar op twee faktore in die dagende nuwe toestand wil ek veral wys. Die een is die diepe verbondenheid van ons binnelandse verhoudinge met ons buitelandse betrekkinge. Dit is ' $n$ verbondenheid wat duidelik gegeld het in die vyftigerjare, toe ons nie goed besef het hoe die Afrika-revolusie sou inslaan in ons binnelandse verhoudinge nie, en trouens gelewe het in die waan dat die standpunt, die regmatige stand- 
punt, dat die wêreld hom nie mag bemoei met ons binnelandse beleid nie, omtrent voldoende was om ons nasionale en internasionale voortbestaan te verseker. Dit was nie en dit is nie. Wat ons hier doen, kan slegs tot beperkte hoogte losgemaak word van wat ons buite ons grense kan bereik, en wat ons dáár bereik, werk noodwendig in op wat ons hier doen. Ons verhoudingspolitiek, of altans die voorstellinge wat daarvan gemaak is en word, is die vernaamste, ek wil byna sê die enigste hindernis vir dié skare van mense wat ons naam en ons belange na buite toe uitdra. Die sukses van ons buitelandse politiek is dus 'n regstreekse funksie van die sukses al dan nie van ons binnelandse verhoudingspolitiek. Ons kan nie na buite slaag as ons nie na binne slaag nie.

Dieselfde verbondenheid is gedemonstreer in die tydperk van krisis wat ons sedert 1960 deurgemaak het - gedemonstreer deur ons vyande, wat goed geweet het dat, vir die sukses van hul planne in die buiteland, hulle spanning en agitasie en onrus binne ons grense nodig het.

Die groot perspektief van leiding en toenemende invloed en samewerking in Afrika is afhanklik van verhoudinge binne Suid-Afrika. Die krag van ons avonture buite die vesting sal afhang van die krag en gesondheid van die vesting self. As die volke van Suid-Afrika nie in vreedsame naasbestaan kan saamlewe nie, soek ons vergeefs na 'n duursame naasbestaan met ons bure. En soos ek gesê het, ek sien geen ander basis vir binnelandse naasbestaan as die beginsel van ontvoogding en die selfbeskikking van ons nie-blanke volke nie. Ons moet trou bly aan ons vryheidsbeginsel, hoe oneindig moeilik die toepassing daarvan ook al in óns omstandighede mag wees, anders sal ons self ons buitelandse beleid van samewerking met gewese koloniale volke saboteer. Ons sal onsself nie net saboteer in Afrika nie, maar in die Weste, want ons betrekkinge met die nasies van Europa en die Westelike Halfrond word tot groot hoogte bepaal deur ons betrekkinge met Swart Afrika, binne sowel as buite ons grense. Hoe beter ons klaarkom met Swart Afrika, hoe meer gesíén word dat ons klaarkom met Swart Afrika, des te meer sal Europese en Amerikaanse bedenkinge teen ons verval. Deur ons samewerking met Lesotho en Malawi het ons reeds nie maar net 'n slag in Afrika geslaan nie, maar in Europa en Amerika.

Dit bring my by die tweede faktor in ons buitelandse betrekkinge waarop ek ten slotte spesiaal wil wys. Daar bestaan 
'n sekere binnelandse verset teen avontuurlikheid en ondernemingsgees, 'n sekere vrees vir kontaminasie en verwatering, 'n agterdog dat, as ons die laer oopmaak en na buite beweeg, ons oorval en vernietig kan word. Is isolasie nie maar die beste nie? Was die isolasie van die laaste jare dan werklik so noodlottig? Ons is tog nog almal hier. Waarom omgang soek met swart ministers en ander uitlanders, en ons gewoontes, ons woorde en op die ou end dalk nog ons beginsels buig ter wille van buitelandse betrekkinge?

Só 'n houding is des te natuurliker vir 'n volk soos die Afrikaners, wat deur hul geskiedenis gekondisioneer is tot waaksaamheid en agterdog teenoor die vreemdeling, en wat buitendien 'n tydperk van gekonsentreerde vestingbou net deurgemaak het en in belangrike opsigte nog nie daarmee klaar is nie. En laat ons maar dadelik toegee dat waaksaamheid gebiedend noodsaaklik bly noudat die toestande vir groter waagsaamheid gunstig lyk.

Tog opper diegene wat geen deug sien in vergesigte buite die vesting nie, die hele kwessie van die doel van ons volksbestaan op 'n manier wat net één antwoord moontlik maak. As ons as volk net vir onsself moet lewe, as ons geen nut het vir die volke rondom ons nie, as ons ons nie geroepe voel tot algemene diens en opheffing en ontwikkeling in Afrika nie, dan is ons op 'n doodlooppad. Dan groei ons in onsself terug.

Dit is nie vir ons gegee om God se patrone vir die toekoms duidelik te sien nie, maar sy onverbiddelike wette en hul werking behoort ons te ken, en een daarvan is dat 'n individu of ' $n$ volk wat nie dien nie, wat geen doel buite sigself het nie, verlore is. Daar kan krag wees in isolasie wat opgedwing word, soos óns krag gevind het in ons isolasie ná 1960 , maar in isolasie wat gesoek word as 'n doel in sigself, as 'n blywende toestand, lê net boosheid.

Dit word welsprekend uitgedruk in die volgende passasie van die Engelse mistikus William Law, wat ek in letters van vuur sou wil skrywe bo Suid-Afrika op hierdie tydstip van ons geskiedenis:

„As 'n verruklike geurige vrug die mag had om homself te skei van die ryke gees en die fyn smaak, reuk en kleur wat hy ontvang uit die krag van die lug en die gees van die son, of as hy in die begin van sy groei kon wegdraai van die son en geen krag daaruit sou ontvang nie, dan sou hy 
staan in sy eie eerste geboorte van gramskap, suurheid, bitterheid, vrankheid, net soos die duiwels wat teruggedraai het in hul eie donker wortel in, en die Lig en Gees van God verwerp het. Sodat die helse aard van 'n duiwel niks anders is nie as sy eie eerste vorme van lewe, teruggetrek of geskei van die hemelse Lig en Liefde; net soos die suurheid, bitterheid en vrankheid van 'n vrug niks anders is nie as die eerste vorm van sy plantelewe, voordat hy die krag van die son en die gees van die lug bereik het. En soos 'n vrug, as hy 'n eie gevoeligheid sou gehad het, vol van foltering sou wees sodra hy opgesluit is in die eerste vorme van sy lewe, in sy eie vrankheid, suurheid en brandende bitterheid, só het die engele, toe hulle teruggedraai het in hierdie selfde eerste vorme van hul eie lewe en weggebreek het van die hemelse Lig en Liefde van God, hul eie hel geword. Geen hel is vir hulle gemaak nie, geen nuwe hoedanighede het in hulle ingekom nie, geen vergelding of pyn van die God van Liefde het op hulle neergedaal nie; hulle het net gestaan in daardie toestand van afskeiding en afsondering van die Seun en die Heilige Gees van God wat hulle uit eie beweging vir hulleself geskep het. Hulle het niks in hulle gehad wat hulle nie van God gekry het nie, die eerste vorme van ' $n$ hemelse lewe; maar hulle het dit gehad in 'n toestand van selffoltering, omdat hulle hulle afgeskei het van die geboorte van Liefde en Lig".

Waar die lig en die lug van diens aan 'n agterlike Afrika dan vir Suid-Afrika, en meer in die besonder vir die Afrikaners aanlok; waar geleenthede vir hulp en opheffing vir ons oopgaan, mag ons ook ter wille van ons eie diepste heil nie ons rug daarna keer nie.

Ons plig is klaarblyklik. Ons is hier nie ferm gewortel om in die "eerste vorme" van ons lewe te bly nie, maar om uit te groei in sinvolle diens.

Afrika het ons nodig, en die wêreld het ons nodig in Afrika. As ons hierin ons bestemming nie kan vervul nie, laat dit dan ten minste nie óns skuld wees nie.

Kaapstad.

P. J. Cillie. 